\title{
Public perception does not accurately reflect resources available to survivors of torture in the United States
}

\author{
Alison L. Burke, MSW
}

Dear Editor,

There is a great deal of misinformation regarding resources available to and obstacles faced by survivors of torture (SOTs) in the United States. A key reason for this is the fact that much of the dialogue centers on the perceived burden of immigration. This rhetoric does not accurately communicate the resources available to refugees and asylum seekers in the US. Since public opinion has, historically, played an influential role in shaping immigration law, creating more effective public policy requires discourse to be rooted in fact.

SOTs generally arrive in the US as asylum seekers or refugees. When refugees arrive, they are granted work authorization and are eligible to receive benefits, such as refugee cash assistance (RCA) and refugee medical assistance (RMA). These benefits end after the refugee has been in the US for 8 months; any additional benefits vary by state (Office of Refugee Resettlement [ORR], 2016; ORR, 2012). In 2016, the US spent $.01 \%$ of the national budget on refugee entrant assistance. (Administration for Children and Families [ACF], 2016, p.15; Congressional Budget Office, 2017). Additionally, many refugees arrive in the US with debt since they are required to repay their travel expenses (US Committee for Refugees and Immigrants [USRI], 2017).

Asylum seekers face more imposing barriers on arrival. They are ineligible for refugee benefits, federal public benefits, and many community resources until they have been granted asylum. In addition, they must wait 150 days after filing for asylum to apply forwork authorization (US Citizenship and Immigration Services [USCIS], 2017). Following this, asylum seekers are subjected to a lengthy, and often retraumatizing, legal system. The first step in this process is the asylum interview, which is generally scheduled two years from the filing date. If the case is referred to court, it is often scheduled 3-5 years from the date of referral (American Immigration Council, 2016). The current backlog of asylum cases creates inconsistent wait times affected by court location and chance (Taxin, 2016).

The Survivors of Torture Program provides rehabilitation services with an annual budget of approximately $\$ 10.5$ million. Unfortunately, some SOTs are unable to access these services due to distance (ORR, 2017).

Significant studies have shown that asylum seekers and refugees do not have a negative social and economic impact. In 2016, the National Academies of Sciences, Engineering, and Medicine released a report that studied immigration trends in the US over the last 20 years. Their assessment found little evidence that immigration affects the employment rates of native-born workers. When employment was negatively impacted, it affected recent immigrants the most. First generation immigrants proved 
costly on state and local levels. However, second generation immigrants had a substantially positive financial impact on government; paying more in taxes than their parents or when compared to the general population (The National Academies of Sciences, Engineering, and Medicine, 2016). The CATO institute also found that immigrants access public benefits less frequently than the native population ( $\mathrm{Ku} \&$ Bruen, 2013). Furthermore, a Danish study found that the average wage increased in communities where refugees had been resettled (Foged, Mette, \& Giovanni Peri. 2016). These studies highlight the economic and social benefits refugees offer their new homes, a fact that is often overlooked in current discourse.

History has shown us that public perception influences policy. The US has instituted policies to restrict immigration since the 1800's, beginning with the Page Act (1875) and the Chinese Exclusion Act (1882). At that time, many Americans disapproved of immigrants' religion and cultural practices, and viewed them as economic competitors. As a result of popular opinion and rhetoric, immigration policy allowed for, and even enforced, preference for and discrimination against certain nationalities (Johnson, 1998, p. $1120 \mathrm{ff}$.).

As the civil rights movement reshaped opinion and rhetoric, Congress passed the Immigration and Nationality Act (1965) to address the inherent discrimination in the immigration system. Although it retained some limitations, the law also allowed for a more diverse immigration system by eliminating the national origins quota system, and barring racial considerations from directly influencing decisions about immigration visas (Johnson, 1998, p. 1133). Currently, public opinion is shifting again.

\section{Current attitudes and opinions}

In general, Americans overestimate rates of immigration and its cost while underestimating immigrants' value and contributions to the US. Research has shown that Americans' attitudes towards immigration are more reflective of the individual's demographics than the actual state of immigration in the US (Murray, et al., 2013). Individuals' opinions of immigrants are also influenced by the immigrants' income, race, social standing, educational level, and legal status (Hainmueller, et al., 2015). These attitudes are seemingly mirrored by media coverage and political rhetoric. One survey found that a majority of Americans believe that "immigrants to the US are making American society better in the long run." However, the same survey found that the majority of respondents also believe that immigrants in the US are making crime and the economy worse (Pew Research Center, 2015). In a recent Ipsos survey, $49 \%$ of Americans worried about immigration's impact on jobs and $60 \%$ were concerned about immigration placing pressure on public services (Duffy, B. et al., 2016).

In February of this year, a draft of President Trump's executive order on immigrants was leaked. While the executive order was never enacted, it created fear that consequences for using public benefits could be introduced after asylees and refugees had already enrolled in the programs (Fix \& Capps, 2017). Additionally, the proposed RAISE Act could greatly affect SOTs. In its current form, the bill would lower the number of refugees allowed into the US to 50,000. It would also make it more difficult, if not impossible, for refugees and asylees to be reunited with their family members (BBC News, 2017).

\section{Impact of political rhetoric}

Since his campaign, President Trump has portrayed immigrants as less deserving and 
less valuable than the native-born population. He has even falsely claimed that veterans are treated worse than undocumented immigrants (Jacabson \& Valverde, 2016). Statements like this risk generating resentment of local immigrant populations. These are not just words -- they have changed the way organizations and people behave. Immigration and Customs Enforcement (ICE) is no longer exempting any class of individuals from removal proceedings and their arrests have climbed 40\% (ICE, 2017). In one case, ICE arrested a man outside of a church that had been set up as a temporary homeless shelter in winter months (Hernandez, Lowery, \& Hauslohner, 2017). In addition the number of hate groups and hate crimes in the US has been increasing since 2015 including a spike following the election (Southern Poverty Law Center [SPLC], 2017). A survey of 10,000 teachers around the country showed heightened anxiety in marginalized students, and an increase of verbal harassment, slurs, and other forms of bigotry (SPLC, 2016).

Immigrants, including survivors of torture, from across the country are reacting to the changing climate. For example, there are accounts from all over the US that food assistance enrollment by eligible immigrants has decreased (Dewey, 2016). In Los Angeles, there have been reports that immigrants have been too afraid of deportation to report sexual assault. Reports of sexual assault by Latinos have dropped 10\% from the same time last year (Queally, 2017). There are even reports that people are avoiding medical care for fear of deportation (Swetlitz, 2017). In my work as a clinical case manager at a survivors of torture program, I have heard multiple clients express fear of deportation, even though they are in the US legally. The full extent of the fear caused by recent statements has yet to be seen and will not be fully known until hate crime, healthcare, and social service information for 2017 is compiled and released.

Words and beliefs are powerful, particularly when ruled by hate and bigotry. More research into how public opinion and rhetoric affect SOTs is needed at this time. It is important to understand how the current dialogue and public opinion impacts the treatment and reception of SOTs by their communities. Additionally, more steps need to be taken to ensure the public has an accurate understanding of the amount spent on helping asylum seekers, asylees, and refugees in relation to the economic benefits. It is my view that now is the time to further research these issues and have an informed debate. People can be controlled by fear and hate but, in my experience, they can also be influenced to show empathy when injustice is explained and exposed.

\section{References}

Administration for Children and Families. (2016). Fiscal Year 2017: Justification of Estimates for Appropriation Committees. Retrieved from https://www.acf.hhs.gov/sites/default/files/olab/ final_cj_2017_print.pdf

American Immigration Council. (2016, August 22). FACT SHEET: Asylum in the United States. Retrieved from https://www.americanimmigrationcouncil.org/research/asylum- unitedstates

Brader, T. et al. (2008, October). What Triggers Public Opposition to Immigration? Anxiety, Group Cues, and Immigration Threat. American Journal of Political Science, 52, 959-978.

BBC News. (2017, August 3). US immigration proposals: What's in the Raise Act? Retrieved from http://www.bbc.com/news/world-us-canada-40814625

Congressional Budget Office. (2017, February 8). The Federal Budget in 2016: An Infographic. Retrieved from https:/www.cbo.gov/publication/52408

Dewey, C. (2017, March 16). Immigrants are going hungry so Trump won't deport them. The Washington Post. Retrieved from https:// www.washingtonpost.com/news/wonk/wp/ 
2017/03/16/immigrants-are-now-cancelingtheir-food-stamps-for-fear-that-trump-willdeport-them/?utm_term $=.97$ fea $143 \mathrm{c} 4 \mathrm{e} 7$

Duffy, B. et al. (2016, July). Global Views on Immigration and the Refugee Crisis. Ipsos MORI. Retrieved from https://www.ipsos-mori.com/ Assets/Docs/Polls/ipsos-global-advisor-immigration-and-refugees-2016-charts.pdf

Fix, M., \& Capps, R. (2017, February). Leaked Draft of Possible Trump Executive Order on Public Benefits Would Spell Chilling Effects for Legal Immigrants. Migration Policy Institute. Retrieved from http://www.migrationpolicy.org/ news/leaked-draft-possible-trump-executiveorder-public-benefits-would-spell-chillingeffects-legal

Foged, M. \& Giovanni P. (2016). Immigrants' Effect on Native Workers: New Analysis on Longitudinal Data.” American Economic Journal: Applied Economics. 8, 2, 1-34

Hainmueller, J. et al. (2015, July). The Hidden American Immigration Consensus: a Conjoint Analysis of Attitudes Toward Immigrants. American Journal of Political Science, 59,3, 529-548.

Hernandez, H.R, Lowery, W., \& Hauslohner, A. (2017, Feb 16). Federal immigration raids net many without criminal records, sowing fear. The Washington Post.

Jacobson, L. (2016, Sept 9). Donald Trump's False Claim Veterans Treated Worse than Illegal Immigrants. Politifact. Retrieved from http://www. politifact.com/truth-o-meter/statements/2016/ sep/09/donald-trump/trump-says-veteranstreated-worse-illegal-immigran/

Johnson, K.R. (1998). The Immigration Laws, and Domestic Race Relations; a "Magic Mirror" into the Heart of Darkness, The Indiana Law Journal. 73, 4, 1111-1160.

Ku, L., \& Bruen, B. (2013, March 4). Poor Immigrants Use Public Benefits at a Lower Rate than Poor Native-Born Citizens. Cato Institute Economic Development Bulletin, 17. Retrieved from https://www.cato.org/publications/economic-development-bulletin/poor-immigrantsuse-public-benefits-lower-rate-poor

Murray, K., et al.(2013). Attitudes Towards Unauthorized Immigrants and Refugees. Cultural Diversity and Ethnic Minority Psychology, 19, 3, 332-341.

The National Academies of Science, Engineering, and Medicine. (2016, September 21). Immigration's long-term Impacts on Overall Waged and Employment of Native-born US Workers. Retrieved from http://www8.nationalacademies. org/onpinews/newsitem.aspx? RecordID $=23550$
Office of Refugee Resettlement. (2016). About Cash \& Medical Assistance. Retrieved from https:// www.acf.hhs.gov/orr/programs/cma/about Office of Refugee Resettlement. (2012, July 12). Asylee Eligibility for Assistance and Services. Retrieved from https://www.acf.hhs.gov/orr/ resource/asylee-eligibility-for-assistance-andservices

Office of Refugee Resettlement. (2017). Survivors of Torture Program. Retrieved from https://www. acf.hhs.gov/orr/programs/survivors-of-torture

Pew Research Center Hispanic Trends (2015, September 28). US Public has Mixed Views of Immigrants and Immigration., Pew Research Center. Retrieved from http://www.pewhispanic. org/2015/09/28/modern-immigration-wavebrings-59-million-to-u-s-driving-populationgrowth-and-change-through-2065/

Southern Poverty Law Center. (2017, February 15). Hate groups increase for second consecutive year as Trump electrifies radical right. Retrieved from https://www.splcenter.org/ news/2017/02/15/hate-groups-increase-secondconsecutive-year-trump-electrifies-radical-right

Southern Poverty Law Center. (2016, November 28). The Trump Effect: The Impact of The 2016 Presidential Election on Our Nation's Schools. Retrieved from https://www.splcenter. org/20161128/trump-effect-impact-2016-presidential-election-our-nations-schools

Swetlitz, I. (2017, February 24). Immigrants, fearing Trump's deportation policies, avoid doctor visits. STAT News. Retrieved from https://www. statnews.com/2017/02/24/immigrants-doctorsmedical-care/

Queally, J. (2017, March 21). Latinos are reporting fewer sexual assaults amid a climate of fear in immigrant communities, LAPD says. LA Times. Retrieved from http://www.latimes. com/local/ lanow/la-me-ln-immigrant-crime-reportingdrops-20170321-story.html

Taxin, Amy. (2016, June 2). Children's asylum approvals vary by US region. The Associated Press. Retrieved from https://apnews.com/ b140ad95d4a646e9aff67b8c80708e57/ap-exclusive-childrens-asylum-approvals-vary-us-region

US Immigration and Customs Enforcement. (2017). Feature: 100 Days of ICE. Retrieved from https://www.ice.gov/features/100-days

US Citizenship and Immigration Services. (2017). Asylum. Retrieved from https://www.uscis.gov/ humanitarian/refugees-asylum/asylum

US Committee for Refugees and Immigrants. (2017). Travel Loan Services. Retrieved from http:// www.uscripayments.org/ 